\title{
Prime Minister revives home care, pharmacare
}

Prime Minister Paul Martin has vowed to develop a 10 -year plan for health care reform that includes national home care and pharmacare programs that will provide "a fix for a generation."

In a major policy speech delivered in Toronto April 16 to the Canadian Club and the Empire Club of Canada, Martin re-committed his government to making health care its top priority. Although he insisted that "reform does not begin with a dollar sign and end with a bunch of zeroes," Martin said that the federal government is "prepared ... to invest more." He did not, however, specify a figure beyond the $\$ 37$ million he said the Liberals have already committed in new money over 5 years.

Just four days after Martin's speech, Health Minister Pierre

$\widehat{0}$ Pettigrew promised a new rela-

tionship with the provinces over

health care, in his own address

票 to a health policy summit in

in Toronto.

The Liberals are widely ex-

pected to call an election later

$\stackrel{\circ}{\circ}$ this year — perhaps as early as this spring - and to make health care the major plank in their campaign.

Citing the need for "publicly funded, universally available health care" that will be there for the baby boom generation's grandchildren, Martin highlighted problems with human resources and waiting lists. The federal government will work with provinces and territories to provide more spaces in medical school for young Canadians and international medical graduates, Martin said. He also committed to finding "an appropriately expanded role for nurse practitioners and other paramedical personnel."

Martin appeared to be promising more transparency about waiting times, saying Canadians need to know how long it will take in their communities for tests, doctor visits, surgery and emergency attention. He also alluded to the need to "build on progress being made in primary care renewal."

Returning to the Liberals' 1997 election platform, Martin revived the notion of improved home and community services and a national pharmaceutical program. Former health minister Allan Rock tried to introduce both, which Rock said ultimately failed because the provinces did not want strings attached to federal transfers. The 2 programs were largely absent from the Liberals' 2000 election platform. But Martin now appears determined to agree with provincial and territorial governments on a 10 -year plan for stable funding. He said he would meet with the premiers this summer "for as long as it takes."

The provinces, except Alberta, were cautiously receptive to Martin's speech. Alberta's health minister says the province opposes any conditions on health care funding.

Pettigrew promised to "encourage partnerships" and avoid "top-down approaches" with the provinces. Both Martin and Pettigrew said Ottawa will be guided by the Romanow Commission's work. - Laura Eggertson, CMAJ

\section{Medical Publishing}

\section{Ex-CMAZ editor retires from international association}

Dr. Bruce Squires, a mentor to medical editors in 77 countries, recently stepped down from the board of the World Association of Medical Editors (WAME) 9 years after he and 21 other medical journal editors founded the "virtual" association.

In his various roles with WAME, the former CMA7 editor-

$\approx$ in-chief (1986-1996)

के helped medical jour-

nals worldwide be-

हु come more profes-

sional and connected. WAME

has 1051 members representing

650 journals, and Squires has

○ virtually "talked" to them all.
After 6 years as a vice-president and 3 as secretary, he will continue to chair the membership committee and run the listserv.

His resignation prompted a deluge of email messages from his many admirers and colleagues, from South America to Iran, India to South Africa.

The seed for WAME was planted in response to concerns about the exclusiveness of the International Committee of Medical Journal Editors in 1993 as editors searched for a way to be more inclusive and encourage dialogue. WAME was born in March 1995 in Bellagio, Italy, at a time when communication using the World Wide Web was just becoming commonplace. Undeterred, the group soon launched the site (www.wame.org).

"We wanted it to be accessible," said Squires. "It was put together to help the smaller or poorer journals, most of which have part-time, volunteer editors with fixed terms and very little experience." WAME also keeps the big guns on target, Squires says. "Since we demand integrity, we have to demonstrate integrity ourselves." Barbara Sibbald, CMAJ 